\title{
Rethinking the Two Margins of Appreciation
}

\author{
Oddný Mjöll Arnardóttir*
}

European Court of Human Rights - Subsidiarity - Margin of appreciation Deference - Theorising the margin of appreciation based on a large case law study The 'systemic' (rethought 'structural') element of the margin of appreciation relies on a functional rationale related to the distribution of tasks within the European system for the protection of human rights and is based on non-merits reasons - The 'normative' (rethought 'substantive') element reflects normative flexibility and is based on merits reasons - Both margins reflect the principle of subsidiarity - The two margins most often interact in partial deference but the systemic margin can also lead to complete deference - Presumptions of complete deference in the case law of the Court - Implications of increased reliance on the systemic margin as the Court moves emphasis from 'substantive' to 'procedural' review.

\section{INTRODUCTION}

The margin of appreciation doctrine is widely commented on, but commentators have nevertheless not been able to explain it to a satisfactory level of clarity. Some works do exist that endeavour to theorise on the doctrine as such, ${ }^{1}$ but the literature has generally been more focused on describing the different situations in

* Prof. dr. Oddný Mjöll Arnardóttir is Professor of human rights law at the University of Iceland. This article is part of a research project on the margin of appreciation, funded by the Icelandic Research Fund. It was drafted during visiting fellowships at iCourts, the Centre of Excellence for International Courts at Copenhagen University and at the European University Institute in Florence. An earlier version was presented at seminars at the University of Copenhagen (iCourts Centre) and the University of Oslo (MultiRights project). I would like to thank George Letsas, Andrew Legg, Urska Sadl and the other participants at the seminars for their feedback; Gunnar Narfi Gunnarsson for assistance with caselaw analysis; and anonymous reviewers for their helpful comments.

${ }^{1}$ Significantly G. Letsas, 'Two Concepts of the Margin of Appreciation', 26 OJLS (2006) p. 705 and A. Legg, The Margin of Appreciation in International Human Rights Law: Deference and

European Constitutional Law Review, 12: 27-53, 2016

(C) 2016 The Author. This is an Open Access article, distributed under the terms of the Creative Commons Attribution-Non Commercial-NoDerivatives licence (http://creativecommons.org/licenses/by-nc-nd/4.0/), which permits non-commercial re-use, distribution, and reproduction in any medium, provided the original work is unaltered and is properly cited. The written permission of Cambridge University Press must be obtained for commercial re-use or in order to create a derivative work. doi:10.1017/S1574019616000018 
which it may be applicable, ${ }^{2}$ and the different factors that may influence it. ${ }^{3}$ The literature theorising the doctrine also remains very eclectic and it seems that the only common themes that have emerged are that the doctrine has multiple forms and that the Court should do more to clarify its contours and underlying rationale. ${ }^{4}$ Indeed, in 2012 it was argued that 'startlingly little' had been written on the conceptual elements of the doctrine, and with respect to offering a justification for it. ${ }^{5}$ The more recent literature has been somewhat focused on arguing that certain aspects of the doctrine could be improved and/or better justified by developing assessment of the quality of domestic procedures as one of the key indicators for strictness or leniency of review, ${ }^{6}$ or as tools to augment the Court's review in cases where a wide margin of appreciation would otherwise be implied. ${ }^{7}$ It has also been argued that such 'procedural review' could even, in many

${ }^{2}$ For example J. Kratochvíl, 'The Inflation of the Margin of Appreciation by the European Court of Human Rights', 29 NQHR (2011) p. 324 at p. 329-335 (norm application, norm definition, choice of means, other uses); S. Greer, The margin of appreciation: interpretation and discretion under the European Convention on Human Rights (Council of Europe Publishing 2000) p. 23-31 (democracy in crisis, balancing against public interest, balancing competing rights, positive obligations, adjectival discretion in defining exceptions, discrimination); S. Greer, The European Convention on Human Rights: Achievements, Problems and Prospects (Cambridge University Press 2006) Ch. 4. See also Arai-Takahashi, supra n. 1, p. 69-78 (fact-finding, evaluating national law, evaluating human rights norms, balancing against public interest, balancing competing rights).

${ }^{3}$ For example Y. Arai-Takahashi, The Margin of Appreciation Doctrine and the Principle of Proportionality in the Jurisprudence of the ECHR (Intersentia 2002); E. Brems, 'The Margin of Appreciation Doctrine in the Case-Law of the European Court of Human Rights', 56 Heidelberg Journal of International Law (1996) p. 240. Much of the literature on influencing factors is focused on specific Convention rights, see for example O. M. Arnardóttir, 'The Differences that Make a Difference: Recent Developments on the Discrimination Grounds and the Margin of Appreciation under Article 14 ECHR', 14 HRL Rev (2014) p. 647.

${ }^{4}$ For example R. St. J. Macdonald, 'The Margin of Appreciation', in R. St. J. Macdonald et al. (eds.), The European System for the Protection of Human Rights (Martinus Nijhoff Publishers 1993) p. 84; Letsas, 'Two Concepts', supra n. 1, p. 706; Shany, supra n. 1, p. 910; Kratochvíl, supra n. 2, p. 354; Greer 2000, supra n. 2, p. 32; J. Gerards, 'Pluralism, Deference and the Margin of Appreciation Doctrine', 17 ELJ (2011) p. 80 at p. 114; P. Popelier and C. Van de Heyning, 'Procedural Rationality: Giving Teeth to the Proportionality Analysis', 9 EuConst (2013) p. 230 at p. 248-249.

${ }^{5}$ Legg, supra n. 1, p. 4.

${ }^{6}$ The point was for example made by Legg, supra n. 1, p. 70; and E. Brems and L. Lavrysen, 'Procedural Justice in Human Rights Adjudication: The European Court of Human Rights', 35 Hum. Rts. Q (2013) p. 176 at p. 199-200.

${ }^{7}$ See Popelier and Van de Heyning, supra n. 4, p. 243; P. Popelier, 'The Court as Regulatory Watchdog: The procedural approach in the case law of the European Court of Human Rights' in P. Popelier et al. (eds.), The Role of Constitutional Courts in Multilevel Governance (Intersentia 2012) p. 249 at p. 265; and C. Van de Heyning, 'No Place like Home: Discretionary space for the domestic protection of fundamental rights' in P. Popelier et al. (eds.), Human rights protection in the European legal order: The interaction between the European and the national courts (Intersentia 2011) p. 65 at p. 95 . 
situations, replace the Court's 'substantive review' on the merits of a case, making the margin of appreciation doctrine redundant in these cases. ${ }^{8}$

Theoretical accounts focused on conceptualising the doctrine as a whole, however, remain few and far between. Recent key contributions of that genre are provided in the works of George Letsas and Andrew Legg, and the scope of this article will be focused on addressing the disagreement that exists between them on how the key element(s) or function(s) of the doctrine should be conceptualised. ${ }^{9}$ For reasons that will be explained below, the starting point will be taken in Letsas' famous identification of a distinction between two concepts of the margin of appreciation, but a rethought conceptualisation will be suggested with different contours and a clearer dividing line between the two key elements of the doctrine. The aim of this article, therefore, is making the margin of appreciation doctrine more intelligible through relatively comprehensive theory building. ${ }^{10}$

The central argument presented is that the margin of appreciation consists of two distinct elements, which each relies on a different kind of rationale and has a different function. Specifically, it will be argued that the 'systemic' element is related to deference to other decision-making bodies for non-merits reasons, and that the 'normative' element is related to the Court's own assessment of merits reasons. The structure of the article is such that it will begin by restating Legg's disagreement with Letsas on the nature of the margin of appreciation. Here, it will also be pointed out how the work of both authors does not speak to some well-established key elements of the doctrine, and how it is also in need of rethinking in light of the Court's more recent case law. The article, then, moves on to provide the rethought theoretical clarification of the two concepts of the margin of appreciation described supra, marrying observations from the case law and the literature on margin of appreciation and subsidiarity with insights from moral reasoning and deference in the context of constitutional law. ${ }^{11}$ It will also

\footnotetext{
${ }^{8}$ J. Gerards, 'The prism of fundamental rights', 8 Eu Const (2012) p. 173 at p. 197-199.

${ }^{9}$ It should be noted that Arai-Takahashi, supra n. 1, has also recently aimed to theorise the doctrine as a whole, but he follows Letsas' dual conceptualisation of two margins of appreciation.

${ }^{10}$ On legal theory building, see C. McCrudden, 'Legal research and the social sciences', 123 L.Q. R. (2001) p. 632 at p. 634; and M. Van Hoecke, 'Legal Doctrine: Which Method(s) for What Kind of Discipline' in M. Van Hoecke (ed.), Methodologies of Legal Research: Which Kind of Method for What Kind of Discipline (Hart 2013) p. 1 at p 14-15.

${ }^{11}$ The case law analysis performed for this study reached all cases categorised as belonging to case reports and importance level 1 on the HUDOC database, pronounced as from 1 January 2006 until 1 April 2015. The search functions available on HUDOC were utilised in conjunction with the above criteria in search for the terms 'margin of appreciation' and 'require strong reasons to substitute'. Older judgments referred to by the Court or identified in the literature as important contributions to the development of the margin of appreciation doctrine were also consulted and relied upon as relevant.
} 
be pointed out how assessment under the systemic margin of appreciation logically precedes normative engagement by the Court, and it will further be argued that the distinction between the two margins has normative implications as the possibility of complete deference is only present under the 'systemic' element of the doctrine. Finally, it will be concluded that the rethought model for the two margins of appreciation is sound in theory and reflective of key elements in the Court's practice. It, thus, provides the keener understanding of the doctrine often called for in the literature and facilitates a normative assessment of the path the Court seems to be embarking on in its recent case law through increased reliance on the quality of domestic procedures as a key element of the doctrine.

\section{TWO RECENT CONCEPTUALISATIONS OF THE MARGIN OF APPRECIATION DOCTRINE AND THE CAUSE FOR A RETHINK}

In his 2012 monograph, Andrew Legg provides a descriptive exposition of the case law and argues that the doctrine of the margin of appreciation is justified by allowing the democratic formation of human rights norms at state level while retaining the international review of states' reasoning in support of the outcome; by the consent of contracting parties as a foundational element of international treaty law; and by deference to greater expertise when relevant. ${ }^{12}$ Drawing on the philosophy of practical reasoning, ${ }^{13}$ he also argues that the doctrine is characterised by assigning weight to 'external factors' relating to these elements (democracy, consensus, expertise). These, then, provide elements of second order reasoning functioning alongside first order reasons, which he argues are related to the nature of different Convention rights and the type of case at stake. ${ }^{14}$ On Legg's account the structure of the Court's reasoning is such that in making its judgments it relies on the first order reasons that relate to the substance or merits of a case, but also on the second order reasons referring to his three types of 'external' non-merits factors that influence the Court's assessment of the first order reasons. ${ }^{15}$ Upon conceptualising the structure of the Court's reasoning in this way, he moves on to challenge the common understanding that the nature of the right or the type of case are also factors that influence the width of the margin. Instead, he argues that

\footnotetext{
${ }^{12}$ Legg, supra n. 1, p. 58. He argues that the theory espoused 'closely corresponds to the practice', and 'enables a coherent exposition of the doctrine' (p. 18). As to the doctrine's legitimacy, a similar account can be found in e.g. P. Mahoney, 'Marvellous Richness of Diversity or Invidious Cultural Relativism', 19 HRLJ (1998) p. 1.

${ }^{13}$ See J. Raz, Practical Reason and Norms (Oxford University Press 1999).

${ }^{14}$ Legg, supra n. 1 , p. 18 and 219.

${ }^{15}$ Id., p. 8-9 and 196.
} 
these are factors that affect the scope created for the functioning of the margin of appreciation proper. ${ }^{16}$ On this understanding, then, the margin of appreciation has no role related to first order reasons on the merits or substance of the right in question. Different substantive elements related to first order reasons, such as the different interests at stake or the question of whether positive obligations are implied or not, create instead something that might be called 'a margin for the margin'. Legg also conceptualises the doctrine as exclusively located on the site of proportionality assessments in the Court's reasoning. ${ }^{17}$ However, in order to do so, he collapses all the different stages and elements of the Court's pattern of analysis into an all-encompassing proportionality assessment that always engages the Court normatively on the merits of the case. ${ }^{18}$ On this understanding, his second order reasons relating to the three influencing factors are never 'exclusionary' in the sense of excluding the Court's own assessments of the case before it. ${ }^{19}$ The doctrine of the margin of appreciation, thus, is 'not to be understood conceptually as akin to non-justiciability'. ${ }^{20}$

The point of Legg's work is to contribute to the debate on the justification of the margin of appreciation, and to theorise on the Court's structure of reasoning under proportionality from the perspective of the philosophy of practical reasoning. His conceptualisation of the doctrine is, in a sense, supportive or instrumental to that aim since the insistence upon a normative engagement by the Court is a key element of the justification offered for the doctrine. The argument is that since the Court is always free to reject the views of another decision-making body when it contemplates deference, ${ }^{21}$ and since the margin of appreciation is

${ }^{16} I d$., p. 200.

${ }^{17}$ Id., p. 37.

${ }^{18}$ Specifically, Legg states that any assessment of state conduct is in effect a proportionality assessment (id., p. 181), and that proportionality is more accurately conceptualised as a tool to define the contours of rights than as a tool for assessing interferences with rights (id, p. 178). This stance also leads to the approach that the distinction between proportionality assessments and definitions of the scope of rights is completely irrelevant (id. p. 55, 66, 190). On the opposite position, arguing that there is an important distinction between the definition of the scope of rights and their application so defined, and that there is no place for the margin of appreciation with respect to the former, see Greer 2006, supra n. 2, p. 212; and J. Gerards and H. Senden, 'The structure of fundamental rights and the European Court of Human Rights', 7 ICON (2009) p. 619 at p. 652. Legg's merger of different functions and analytic techniques in the Court's jurisprudence into 'proportionality' is not followed in the present article, as it does not reflect the different stages in the Court's reasoning accurately enough, and masks important differences in the function and rationale for the margin of appreciation doctrine as it applies to these different stages.

${ }^{19}$ Legg, supra n. 1, p. 19.

${ }^{20} I d$., p. 36. He nevertheless hints at possible unreviewability in the context of deference to UN Security Council Resolutions (id., p. 139) and argues that there is generally more reason for deference to international organisations than states (id., p. 144).

${ }^{21} I d$., p. 23. 
always located on the reconceptualised all-encompassing proportionality assessment that engages the Court normatively, ${ }^{22}$ the doctrine is justified. Were it otherwise, it would lead to an 'abdication of judicial responsibility' under the Convention. ${ }^{23}$ This conceptualisation of the doctrine in the Court's jurisprudence, however, betrays the actual practice of the Court whereby, as we shall see, it often does give full deference. The Court can, of course, decide not to, which rescues that part of Legg's justificatory argument, which may also be taken to apply to those elements of the margin of appreciation that govern strictness of review under proportionality. But the insistence upon normative engagement, for example, does not hold with respect to the 'fourth instance doctrine', which is not tackled in Legg's descriptive case law analysis. This element of the larger construct of the margin of appreciation doctrine applies when the Court is asked to reassess how national courts dealt with the establishment of fact or how they interpreted and applied national law. ${ }^{24}$ When such issues arise the Court, as a general rule, categorically waives the jurisdiction to deal with them de novo. In cases of this kind, the Court for example expressly reasons that it 'must grant substantial deference ${ }^{25}$ or give 'due deference ${ }^{26}$ to the national courts, or that this is a matter which primarily lies within the competence of the domestic courts. ${ }^{27}$ In this respect, the Court relies on the argument that the domestic courts are 'better placed and equipped' to resolve questions of this kind, ${ }^{28}$ and/or that it is 'not in a position' to do so itself. ${ }^{29}$ The Court's rationale for this extensive deference, of course, is generally based on the fact that it is not set up with the competence or function of a higher court within the internal legal systems of the Contracting

${ }^{22}$ Id., p. 37.

${ }^{23}$ Id., p. 23. Correspondingly Legg refers to situations where the Court does not engage normatively as instances of 'servility' (id., p. 23) or 'obedience' (id., p. 137) to others, which he considers to have no place in the Court's jurisprudence.

${ }^{24} \mathrm{On}$ the fourth instance doctrine as synonymous with the margin of appreciation see J. Christoffersen, Fair Balance: Proportionality, Subsidiarity and Primacy in the European Convention on Human Rights (Martinus Nijhoff Publishers 2009) p. 238-239. The Court, indeed, seems to use the two terms interchangeably, see, for example, ECtHR 19 October 2006, Case No. 65550/01, Koval v Ukraine, para. 118, where the Court referred to the national court's margin of appreciation 'in the admission and assessment of evidence'. On the fourth instance doctrine generally, see M. Dahlberg, ' ...It is not its task to Act as a Court of Fourth Instance': The Case of the European Court of Human Rights', 7 EJLS (2014) p. 84; Arai-Takahashi, supra n. 3, p. 235; and European Court of Human Rights, Practical Guide on Admissibility Criteria, 31 March 2011, < www.dp-rs.si/fileadmin/ dp.gov.si/pageuploads/RAZNO/Admissibility_guide_ENG.pdf>, visited 8 February 2016.

${ }^{25}$ ECtHR 26 June 2009, Case No. 46423/069, Beganović v Croatia, para. 78.

${ }^{26}$ ECtHR 15 September 2009, Case No. 10373/05, Moskalv Poland, para. 56.

${ }^{27}$ ECtHR 20 September 2011, Case No. 14902/04, Oao Neftyanaya Kompaniya Yukos v Russia, para. 559.

${ }^{28}$ Koval v Ukraine supra n. 24, para. 118.

${ }^{29}$ ECtHR 19 February 2009, Case No. 4063/04, Marchenko v Ukraine, para. 48. 
States, but only as a subsidiary mechanism for reviewing Convention compatibility. It, therefore, does not act as an appeals court ('fourth instance') for reviewing the quality of the domestic court's judgment under national law. It is, accordingly, not the Court's 'task' or 'role' to pronounce on questions of this kind, ${ }^{30}$ and the result in most cases is that it leaves the task completely up to the national courts. ${ }^{31}$ It is important, therefore, to avoid the mistake of taking Legg's work and argument for justifying the margin of appreciation as meaning descriptively/conceptually that the margin of appreciation always has the function that the Court engages normatively. ${ }^{32}$

In his well-known 2006 article titled 'Two Concepts of the Margin of Appreciation' George Letsas provided a very different conceptualisation of the doctrine. On his reading, the Court uses the margin of appreciation 'for both saying that the applicant did not, as a matter of human rights, have the right she claimed, and for saying that it will not substantively review the decision of national authorities.' ${ }^{33}$ He coined the phrases 'substantive' and 'structural' margin of appreciation to describe this difference, and argued that the failure to distinguish between the two explains a lot of the confusion and controversy surrounding the doctrine. ${ }^{34}$ Under Letsas' structural margin, the Court will defer to state authorities and refrain from reviewing their action on the ground that they are 'better placed' in the situation at hand. This concept is, therefore, supported by an argument from institutional competence, which he equates with the principle of subsidiarity, while noting that the principle does not only encompass a chronological or procedural priority for the national authorities, but also a normative one. ${ }^{35}$ The substantive concept of the margin of appreciation in Letsas' construction concerns the balancing of public and private interests under the Convention. The 'main idea' behind it, he argued, is simply making a 'very general and simple point about the limitability or non-absoluteness of the Convention rights'. ${ }^{36}$ Explaining which categories of cases belong to which kind of margin, Letsas further argued that the structural element applies when the Court refrains from review on the basis that the

\footnotetext{
${ }^{30}$ ECtHR 11 April 2006 Case No. 19324/02, Léger v France, para. 72.

${ }^{31}$ The Court, however, retains the power to intervene and engage in its own assessments if the facts of the case reveal arbitrariness or manifest deficiencies in the way the domestic courts handled the relevant issues, see, for example, Beganović v Croatia, supra n. 25, paras. 78 and 85.

${ }^{32}$ Examples where the Court does not engage normatively seem to be interpreted by Legg as 'failure' and 'mistakes' (Legg, supra n. 1, p. 27 and 36). Cases that exhibit the well-established main approach of complete or almost complete deference to domestic courts' interpretation of domestic law, further, seem to be interpreted as exceptions (id., p. 173).

${ }^{33}$ Letsas, supra n. 1, p. 706.

${ }^{34} \mathrm{Id}$.

${ }^{35} I d .$, p. $720-722$.

${ }^{36}$ Id., p. 711 and 714 .
} 
issue is politically sensitive (notably under Article $15 \mathrm{ECHR}$ ) and/or there is no consensus among the Contracting States, ${ }^{37}$ while the substantive concept is at stake when reviewing limitations, exceptions or restrictions on rights. ${ }^{38}$

Letsas and Legg disagree not only on how to conceptualise the margin of appreciation doctrine, but also on what is the best theory of rights. Legg's account is based in interest-based theories of rights and the philosophy of practical reasoning. ${ }^{39}$ His analysis revolves around the normative role of the margin of appreciation, and he sees it as almost synonymous with interpretation of rights. ${ }^{40}$ The point of Letsas' article is, in a sense, opposite to Legg's bid for justifying the doctrine. It was intended rather to exhibit its normative emptiness and how the analysis of human rights questions needs to be normatively anchored in theories originating elsewhere; and to advance the Dworkinian reason-blocking approach as the preferred theory of rights. ${ }^{41}$ As Letsas' conceptualisation of the doctrine is based in interpretivism, he does not set out to provide a systematic exposition of the Court's case law like Legg. Indeed, he cautions that his account of the two margins of appreciation might not necessarily be 'the one that the ECtHR judges, one by one, share or have fully developed in their judgments. ${ }^{42}$ He nevertheless cites around 40 judgments to exhibit how his two conceptions of the doctrine are anchored in the case law. Despite these case law references, it is important not to make the mistake of thinking that Letsas' two concepts accurately capture the whole of the Court's practice under the margin of appreciation since he also does not tackle the case law on the well-known 'fourth instance doctrine'.

Upon close analysis of the case law, it is also difficult to detect a clear difference in kind between the margin of appreciation applied when balancing interests in connection with highly-sensitive or contested political and moral questions, which Letsas associated with his structural margin of appreciation, ${ }^{43}$ and otherwise under limitable rights, which he associated with the substantive margin. ${ }^{44}$ The Court's

${ }^{37} \mathrm{Id}$., p. $722 \mathrm{ff}$.

${ }^{38}$ Id., p. $710 \mathrm{ff}$.

${ }^{39}$ J. Finnis, Natural Law and Natural Rights (Oxford University Press 1980); Raz, Practical Reason and Norms, supra n. 13; J. Raz, The Morality of Freedom (Oxford University Press 1986).

${ }^{40}$ Legg, supra n. 1, p. 107: 'Much of this book relates to the interpretation of the Treaties'.

${ }^{41}$ Letsas supra n. 1, p. 710 and 731-732. See generally R. Dworkin, Taking Rights Seriously (Harvard University Press 1978).

${ }^{42}$ Letsas, id., p. 706. Legal interpretivism is primarily based in Ronald Dworkin's body of work. In contrast with legal positivism it offers a constitutive explanation of legal rights according to which the practice of legal institutions is not determinative alone. Instead, and perhaps more importantly, moral principles have a fundamental justificatory role. See N. Stavropoulos, Legal Interpretivism, Stanford Encyclopedia of Philosophy (Edward N. Zalta ed., Summer 2014 Edition) < plato.stanford. edu/archives/sum2014/entries/law-interpretivist/ >, visited 8 February 2016.

${ }^{43}$ Letsas, supra n. 1, p. 722-723.

${ }^{44} I d$., p. 711. 
methodology of balancing all the relevant (merits and non-merits) reasons is, of course, the same in both types of cases, and the margin of appreciation therefore has the same overall function. However, as established by many a commentator and confirmed in the case law analysis performed for the present study, the margin of appreciation is generally wider in the former situation. ${ }^{45}$ This, however, is a difference of degree and not one of kind. A wider margin is, in fact, also generally implied when the Court balances interests in cases involving policy-making in the socioeconomic sphere, ${ }^{46}$ and in cases where the Court engages normatively with the balancing of competing individual interests, ${ }^{47}$ but it is not altogether clear how such cases would fit in the overall scheme suggested by Letsas.

Subsequent to Legg's and Letsas' work, the Court has also devised new uses for the margin of appreciation doctrine in cases where two protected private interests collide and have to be balanced against each other under competing Convention rights. Their conceptualisations of the margin of appreciation seem incapable of capturing this important development, which exhibits the increased proceduralisation of the Court's review through the creation of presumptions of complete deference on substantive proportionality assessments in concreto (see infra). Legg's insistence that the doctrine is exclusively located on the Court's

\footnotetext{
${ }^{45}$ For example under Art. 8, see ECtHR 16 December 2010, Case No. 25579/05, A, B and $C \mathrm{v}$ Ireland, para. 233 on abortion legislation in Ireland; and ECtHR 10 April 2007, Case No. 6339/05, Evans v United Kingdom, para. 77 on the use of embryos. In the context of Art. 9 and Art. 2 of Protocol 1, compare the wide margin of appreciation applied in relation to religious symbols in the classroom in ECtHR 4 December 2008, Case No. 27058/05, Dogru v France and ECtHR 18 March 2011, Case No. 30814/06, Lautsi and Others v Italy, and the narrower margin applied in relation to conscientious objection to military service in ECtHR 7 July 2011, Case No. 23459/03, Bayatyan v Armenia or the dissolution of a religious community in ECtHR 10 June 2010, Case No. 302/02, Jehovah's Witnesses of Moscow and Others v Russia. See generally also J. Schokkenbroek, 'The Basis, Nature and Application of the Margin-of-Appreciation Doctrine in the Case-Law of the European Court of Human Rights', 19 HRLJ (1998) p. 34; Arai-Takahashi, supra n. 3, p. 206-212; and Legg, supra n. 1, p. 86-88.

${ }^{46}$ For example, under Art. 8, the Court often refers to a wide margin of appreciation in relation to social or economic policy or technical issues, see, for example, ECtHR 2 November 2010, Case No. 3976/05, Şerife Yiğit v Turkey, para. 100. A wide margin of appreciation is also habitually referred to in relation to substantive assessments under Art. 1 of Protocol 1, see, for example, ECtHR 19 June 2006, Case No. 35014/97, Hutten-Czapska v Poland, paras. 223-234 and ECtHR 15 March 2007, Case Nos. 43278/98 etc., Velikovi and Others v Bulgaria, paras. 179-180. Under Art. 2 of Protocol 1, there is also a wide margin of appreciation for the 'setting and planning of the curriculum', see ECtHR 29 June 2007, Case No. 15472/02, Folgerø and Others v Norway, para. 84 and Lautsi and Others v Italy, supra n. 45, para. 69. See generally also Schokkenbroek, supra n. 45, p. 34; and AraiTakahashi, supra n. 3, p. 214-215.

${ }^{47}$ ECtHR 24 July 2012, Case No. 40721/08, Fáber v Hungary, para. 42 (balancing under Arts. 10 and 11); ECtHR 12 September 2011, Case Nos. 28955/06 etc., Palomo Sánchez and Others v Spain, para. 54 (balancing under Arts. 8 and 10). Recently, the Court has even refrained from engaging normatively in cases of this kind, see infra.
} 
own proportionality assessments does not seem to make much sense in light of such judgments. ${ }^{48}$ As they concern limitations on rights and balancing of competing interests, they would seem to belong to Letsas' 'substantive' concept of the margin of appreciation, which implies a more thorough 'substantive review'. However, as the Court is in effect saying that 'it will not substantively review the decision of national authorities $^{\text {, }}$ in in such judgments, they would also seem to belong to his 'structural' margin of appreciation, which he reserved for the most deferential case law.

The contributions of Legg and Letsas are certainly important and strong in theory, but it cannot be denied that both have the weakness of not addressing the full extent of the Court's case law under the margin of appreciation doctrine. Recent developments on the margin of appreciation, further, do not seem to fit within their conceptualisations of the doctrine. It seems appropriate, therefore, to revisit the issue of whether an internally consistent conceptual framework can be constructed whereby the many different elements of the margin of appreciation as it appears in the case law of the Court can be understood as coming together at the level of (relatively) coherent legal doctrine. ${ }^{50}$

\section{THE RETHOUGHT TWO MARGINS OF APPRECIATION}

The identification of two different functions for the margin of appreciation doctrine in the case law of the Court

Irrespective of any reservation regarding the completeness of the 'structural' and 'substantive' concepts of the margin of appreciation in Letsas' construction, he certainly seems to have pointed towards something real in the case law. Other commentators have indeed also noted something similar. In fact, Letsas sought inspiration from R. St. J. Macdonald, who during his time as a judge at the European Court of Human Rights originally conceptualised the margin of appreciation doctrine as operating on a spectrum ranging from total deference indicating 'unreviewability', through intermediate positions, to the most stringent standard of justification in the Court's review, and conceptualised these two functions as those of 'reviewability' and 'justifiability. ${ }^{51}$ In the first comprehensive

\footnotetext{
${ }^{48}$ Also, when discussing 'external factors' influencing the balancing of conflicting Convention rights, Legg only addressed deference to the domestic legislature, but not to the domestic courts, see Legg, supra n. 2, p. 83-85.

${ }^{49}$ Letsas, supra n. 1, p. 721.

${ }^{50}$ Due to the unclear and confused contours of the margin of appreciation, some authors have questioned whether it can be referred to as 'doctrine' proper, see Greer 2000, supra n. 2, p. 32.

${ }^{51}$ Similarly, he also argued that the confusion between the two functions was a problematic element of the case law and that the distinction was more or less lost on the doctrine as it had evolved in the case law of the Court, see Macdonald, supra n. 4, p. 84-85.
} 
study of the development of the margin of appreciation in the case law of the Court, Howard Yourow also referred to the doctrine as a multifunctional tool, identifying two key functions: formal standards of deference on one hand, and substantive interpretation on the other. ${ }^{52}$ Further, in 2006, Yuval Shany argued that there was such a thing as a general margin of appreciation doctrine in international law and contended that it had two principal elements. While noting that international courts do not generally distinguish between them, he argued that the first element had to do with 'judicial deference', where international courts should refrain from reviewing national decisions de novo, and that the second element indicated 'normative flexibility', allowing different interpretations of the same norm depending on context. ${ }^{53}$ Finally, Dean Spielmann, the former president of the European Court of Human Rights, has recently presented his vision of the margin as having on one hand a 'normative' function, while on the other hand pursuing also a separate 'systemic' objective. ${ }^{54}$ However, while arguing that a selection of recent judgments exhibits the systemic objective of the margin of appreciation, he does not set out to give the whole picture of the doctrine or to elaborate in a broader context the dividing line between the two different types of margin. ${ }^{55}$

A certain common ground on the existence of two key elements appears across all the above attempts to conceptualise the doctrine of the margin of appreciation, but there is no consensus or clarity on how to draw the line for dividing the systemic ('structural', 'reviewability', 'deference') and normative ('substantive', 'justifiability', 'normative flexibility') elements of the doctrine, or on how to identify and locate the two functions in the case law. Macdonald, like Letsas, for example, speaks of total deference ('unreviewability') at the far end of the margin of appreciation spectrum, while Shany, like Legg, argues that total deference is not a possibility under the doctrine. ${ }^{56}$ Similarly, Yourow links the weighing and balancing of claims and defences, in accordance with European consensus, to the

\footnotetext{
${ }^{52}$ H. C. Yourow, The Margin of Appreciation Doctrine in the Dynamics of European Human Rights Jurisprudence (Martinus Nijhoff Publishers 1996) p. 195-196. Although categorised into four components, the two elements also appear indirectly in Arai-Takahashi's conceptualisation, see AraiTakahashi, supra n. 3, p. 236-242. In subsequent work, he has adopted Letsas' dual conceptualisation as a heuristic tool, see Arai-Takahashi, supra n. 1, p. 90 and 94.

${ }^{53}$ Shany, supra n. 1, p. 909-910, associating the former with norm-application, and the latter with norm-interpretation.

${ }^{54}$ D. Spielmann, 'Whither the Margin of Appreciation', 67 CLP (2014) p. 49.

${ }^{55}$ Similarly, see the discussion by Judge Robert Spano of selected judgments as exhibiting the 'process of reformulating or refining the concepts of subsidiarity and the margin of appreciation', R. Spano, 'Universality or Diversity of Human Rights? Strasbourg in the Age of Subsidiarity', 14 HRL Rev. (2014) p. 487 at p. 492.

${ }^{56}$ Macdonald, supra n. 4, p. 84; Letsas, supra n. 1, p. 706; Shany, supra n. 1, p. 910; Legg, supra n. 1, p. 36 .
} 
normative or interpretational element of the doctrine, while Letsas, on the other hand, sees lack of consensus cases as the primary example of the structural margin of appreciation. ${ }^{57}$ Letsas' concept of the structural margin also is not framed with reference to the Court's clearest examples of systemic deference under the 'fourth instance doctrine', and was conceptualised before the existence of Spielmann's examples of the Court taking a 'clear stance of principle' on the 'systemic' function of the doctrine. ${ }^{58}$

On the back of this literature, it can nevertheless be taken as established that there is consensus that there is some kind of a distinction between two different functions under the margin of appreciation doctrine. But the present confusion and inconsistency on the nature and contours of this distinction inevitably leads to the conclusion that while these works provide a good starting point, they do not sufficiently capture the whole of the margin of appreciation doctrine or the direction it is taking in Court's more recent case law. The time has therefore come to rethink and develop in a more holistic manner the way in which the two concepts of the margin of appreciation have been theorised, and to elaborate on their contours, interrelationship and underlying rationale. In the following, for reasons of clarity and specification from earlier works, Spielmann's terminology of a 'systemic' and a 'normative' function will be adopted.

\section{The two elements of the principle of subsidiarity}

When aiming to rethink the margin of appreciation doctrine, it seems appropriate to note the well-established fact that it provides the doctrinal expression of the principle of subsidiarity. The two were first expressly united in the Handyside judgment, where the Court reasoned that the former was a consequence of the latter, ${ }^{59}$ and this understanding of the relationship between the two has since been carved in stone in the Court's case law and in Protocol 15 to the Convention, which will add reference to the pair into the Convention's Preamble. ${ }^{60}$ It is beyond doubt, therefore, that subsidiarity provides the normative basis for the doctrine. The margin of appreciation should accordingly reflect the principle of subsidiarity.

The different elements of the principle of subsidiarity, tensions with the ideal of universal human rights and its development in national, European and international law have all been elaborated on in the literature. ${ }^{61}$ In the specific

\footnotetext{
${ }^{57}$ Yourow, supra n. 52, p. 195; Letsas, supra n. 1, particularly p. 724-729.

${ }^{58}$ Spielmann, supra n. 54, p. 63; Letsas supra n.1, p. 723.

${ }^{59}$ ECtHR 7 December 1976, Case No. 5493/72, Handyside v United Kingdom, para. 48.

${ }^{60}$ Protocol No. 15 amending the Convention for the Protection of Human Rights and Fundamental Freedoms (adopted 24 June 2013), CETS No. 213.

${ }^{61}$ See e.g. M. Evans and A. Zimmermann (eds.) Global Perspectives on Subsidiarity (Springer 2014). For contributions in the field of international law see A. Føllesdal, 'The principle of
} 
Convention context, the principle is most clearly expressed in Articles 1 and 19 ECHR, which stipulate that it is the primary responsibility of the Contracting Parties to secure the rights and freedoms defined in the Convention and limit the Court's task to ensuring the observance of their obligations under the Convention. Article 13 and $35 \mathrm{ECHR}$, further, stipulate that individuals shall have an effective remedy before a national authority in cases of violations, and that all domestic remedies must be exhausted before a case can be brought before the European Court of Human Rights. Together these provisions express the fundamental elements of what has in the Court's practice become the larger construct of a Convention principle espousing the 'subsidiary nature of the international machinery for collective enforcement established by the Convention'. ${ }^{62}$ More precisely, the Court has recently stated about itself that 'within the scheme of the Convention it is intended to be subsidiary to the national systems safeguarding human rights', and emphasised that '[s]ubsidiarity is at the very basis of the Convention'.63

In the abstract, the principle of subsidiarity 'divides decision-making in society, considering values of efficiency, liberty and justice. ${ }^{64}$ It represents the normative vision of agency that larger or more centralised units should not usurp functions that smaller or more local units are able to perform well enough. The underlying presumption is that, unless proven otherwise, smaller or local units are best suited to exercise power over their own affairs. Hence, the Court's habitual invocation of the principle, and the margin, in the terms that due to their 'direct democratic legitimation ${ }^{\text {,65 }}$ or 'direct knowledge of their society and its needs', the national

subsidiarity as a constitutional principle in international law', 2 Global Constitutionalism (2013) p. 37; D. Shelton, 'Subsidiarity and Human Rights Law', 27 HRLJ (2006) p. 4; P. G. Carozza, 'Subsidiarity as a Structural Principle of International Human Rights Law', 97 AJIL (2003) p. 38; and W. M. Carter, 'Rethinking Subsidiarity in International Human Rights Adjudication', 30 Journal of Public Law and Policy (2008) p. 319. For contributions in the EU context see G. A. Bermann, 'Taking Subsidiarity Seriously: Federalism in the European Community and the United States', 94 Colum.L.Rev. (1994) p. 332; T. Schilling, 'A New Dimension of Subsidiarity: Subsidiarity as a Rule and a Principle', 14 Y.B. Eur. L. (1995) p. 255; G. de Búrca, 'The Principle of Subsidiarity and the Court of Justice as an Institutional Actor', 36 JCMS (1998) p. 217; and T. Horsley, 'Subsidiarity and the European Court of Justice: Missing Pieces in the Subsidiarity Jigsaw?', 50 JCMS (2012) p. 267.

${ }^{62}$ ECtHR 23 July 1968, Case Nos. 1474/62 etc., Case relating to certain aspects of the laws on the use of languages in education in Belgium $\mathrm{v}$ Belgium, part IA, para. 4.

${ }^{63}$ ECtHR 15 March 2012, Case Nos. 39692/09 etc., Austin and Others v United Kingdom, para. 61. For a recent review of the principle of subsidiarity as it appears in the case-law of the ECtHR, see A. Mowbray, 'Subsidiarity and the European Convention on Human Rights', 15 HRL $\operatorname{Rev}(2015)$ p. 313.

${ }^{64}$ Shelton, supra n. 61, p. 5.

${ }^{65}$ ECtHR 8 July 2003, Case No. 36022/97, Hatton and Others v United Kingdom, para. 97. 
authorities are 'in principle better placed' than an international court to perform the relevant assessments. ${ }^{66}$

It has been pointed out in academic commentary how the principle of subsidiarity in international human rights adjudication has a dual rationale that encompasses both functional and normative justifications. ${ }^{67}$ The functional one is related to efficiency and competence, as it recognises that smaller or local units closer to the events are better equipped to deal with them and accepts the limited resources at the Strasbourg Court's disposal. But there is also another functional concern behind the judicial restraint implied by the principle of subsidiarity. This is the simple fact of Contracting State consent as the foundation of Convention obligations and the relatively weak enforcement mechanism upon which the system rests, which calls for a certain amount of respect or deference to the Contracting Parties. ${ }^{68}$ As the functioning of the Convention system depends very much on the extent to which the judgments of the Court are received as legitimate by the Contracting States, the language of subsidiarity provides a particularly effective legitimising strategy. ${ }^{69}$ Normatively, however, the principle of subsidiarity when applied to human rights performance rests upon the rationale that it expresses respect for the self-determination of individuals, or groups of individuals through democratic processes. ${ }^{70}$ As such it facilitates the pluralism and diversity associated with democratic society, ${ }^{71}$ and recognises that there may exist different, but equally valid, ways of ensuring the same Convention rights. Subsidiarity, however, has always been 'a somewhat paradoxical principle' as it on one hand limits intervention from a larger or more centralised unit, while at the

${ }^{66}$ ECtHR 7 July 2011, Case No. 37452/02, Stummer v Austria, para. 89.

${ }^{67}$ E.g. L. R. Helfer, 'Redesigning the European Court of Human Rights: Embeddedness as a Deep Structural Principle of the European Human Rights Regime', 19 EJIL (2008) p. 125 at p. 128.

${ }^{68}$ Carter, supra n. 61, p. 319-320; Macdonald, supra, n. 4, p. 123.

${ }^{69}$ Carozza, supra n. 61, p. 40, refers to the principle as 'a conceptual and rhetorical mediator between supranational harmonization and unity, on the one hand, and local pluralism and difference, on the other.' See also J. Raz, 'On the Authority and Interpretation of Constitutions: Some Preliminaries' in L. Alexander (ed.), Constitutionalism: Philosophical Foundations (Cambridge University Press 2001) p. 152 at p. 173-174 and 188-189, who highlights the legitimating function of 'non-merit reasons' when they are relied upon in the context of constitutional interpretation.

${ }^{70}$ Carozza, supra n. 61, p. 43-44. Føllesdal, supra n. 61, p. 61-62 focuses on the normative role of justifying or legitimising action on part of the international human rights regime, arguing that current state-centric versions of the principle are problematic and that a focus on individual interests would be a more plausible way of imbuing the principle with normative force. See also A. Føllesdal, 'Squaring the Circle at the Battle at Brighton: Is the War between Protecting Human Rights or Respecting Sovereignty Over, or Has it Just Begun?' in O. M. Arnardóttir and A. Buyse (eds.), Shifting Centres of Gravity of Human Rights Protection Rethinking Relations between the ECHR, EU and National Legal Orders (forthcoming, Routledge 2016), on file with author.

${ }^{71}$ In the Court's own words, pluralism is 'indissociable' from a democratic society, see e.g. ECtHR 10 November 2005, Case No. 44774/98, Leyla Şahin v Turkey, para. 104. 
same time empowering it and justifying its action in those cases where the smaller or more local unit cannot or does not perform well enough. ${ }^{72}$

The complexity of the principle of subsidiarity and its twofold rationale is also reflected in the fact that it has different functions, as elaborated on by Paolo Carozza. He sees the principle, to a certain extent, as 'concerned with the distribution of competences among different levels of governance ${ }^{73}$ - as per the functional rationale - and to a certain extent as instrumental in explaining why international human rights law is 'still characterized less by fully articulated normative content than by the interpretive discretion that it leaves to states ${ }^{74}$ - as per the normative rationale. In a more concise form these dual functions may be referred to in the terms that the principle of subsidiarity regulates 'how to allocate or use authority within a political or legal order. ${ }^{75}$ The principle of subsidiarity in theory, therefore, has a systemic dimension related to the distribution of competences and tasks, and a normative dimension that guides or justifies how authority is used, which accounts for the normative elasticity characteristic of the interpretation of international human rights norms. ${ }^{76}$

These different elements of the principle of subsidiarity have, however, not been made explicit in the Court's jurisprudence. When the Court refers to subsidiarity and the 'better placed' argument it may, therefore, be referring to either of the two conceptions of the principle; the systemic or the normative one. The same can generally be said about the Court's use of the margin of appreciation. As the margin of appreciation doctrine has evolved as an offspring of the principle of subsidiarity, both its functions nevertheless carry through to the doctrine. The margin of appreciation will, thus, take on different hues depending on whether it is employed as the expression of the systemic relationship between the national and supranational levels (who decides what and when), or whether it has a

${ }^{72}$ Carozza, supra n. 61, p. 44. Mowbray, supra n. 63, p. 340 notes how the principle of subsidiarity has indeed also been relied on by the Court to legitimate its judicial intervention when the domestic level has clearly failed, referring to ECtHR 13 December 2012, Case No. 39630/09, El-Masriv The Former Yugoslav Republic of Macedonia regarding defects in fact-finding at the national level; and ECtHR 7 February 2013, Case No. 16574/08, Fabris v France regarding clear disregard for well-established ECtHR case law.

${ }^{73}$ Carozza, supra n. 61, p. 57.

${ }^{74}$ Id., p. 62.

${ }^{75}$ Føllesdal, supra n. 61, p. 37 (emphasis added). In the EU context, Bermann, supra n. 61, p. 366-367 speaks of four functions: legislative function; interpretative function; a function of conferring legality; and a function in terms of confidence-building. All are in a sense sub-categories or consequences of the principle's key functions of governing the allocation or use of power.

${ }^{76}$ In the Convention context, more specifically, Herbert Petzold actually already in 1993 identified that the principle of subsidiarity had taken on both connotations in the Court's case law, see H. Petzold, 'The Convention and the Principle of Subsidiarity' in R. St. J. Macdonald et al. (eds.), The European System for the Protection of Human Rights (Martinus Nijhoff Publishers 1993) p. 49. 
normative function when interpreting and applying the Convention within the scope of the Court's review as defined by this systemic relationship (and how).

Looking at the different attempts to identify and explain the different functions of the margin of appreciation doctrine described supra, we can discern that even though they conceptualise the dividing line in different terms, they all straddle this difference between the systemic and the normative in one way or another. An explicit link with the two functions of subsidiarity is, however, generally absent. ${ }^{77}$ Letsas is the first one to make that connection, via references to Petzold's work on subsidiarity. Curiously, however, he does not associate his substantive concept of the margin of appreciation with the principle of subsidiarity in its normative conception. ${ }^{78}$ Unlike Carozza, who forges a link between the function of the margin of appreciation in the interpretative process and the normative element of the principle of subsidiarity, Letsas does not. ${ }^{79}$ Instead, he seems to consider both elements of the principle of subsidiarity as reflected in his structural concept of the margin of appreciation. ${ }^{80}$ It is submitted that the better way forward to providing a satisfactory explanation of the margin of appreciation in the case law of the European Court of Human Rights is to bring understanding of how the principle of subsidiarity has a dual justification and function to bear upon our understanding of the margin of appreciation doctrine. We will proceed, therefore, on the understanding that the principle of subsidiarity and the margin of appreciation doctrine have a dual justification (functional and normative), and that they have a dual function (the systemic distribution of competences between decision making bodies and the normative function of allowing pluralism and flexibility in the interpretation and application of rights). This difference is captured by employing the terms 'systemic' and 'normative' to describe each element.

\section{Systemic non-merits reasons and normative merits reasons}

The distinction between the systemic and normative elements of the margin of appreciation doctrine is also important because different types of reasoning are

\footnotetext{
${ }^{77}$ Macdonald, supra n. 4 and Shany, supra n. 1 hardly mention subsidiarity, and while Spielmann, supra n. 54, does, he makes no connection between the different functions of the principle and the different functions of the margin of appreciation. In 2002 Arai-Takahasi, supra n. 3, p. 236 and 239-240 discussed subsidiarity as related only to one of the four elements of the margin of appreciation he identified (balancing sovereignty; Convention mandated deference; 'fourth instance' doctrine and the principle of subsidiarity; and contested value-judgments). In 2013 he, however, presented an updated account, reflecting Letsas' conceptualisation of the link between subsidiarity and margin of appreciation, see Arai-Takahashi, supra n. 1, p. 90-94.

${ }^{78}$ Subsequent works have not provided further articulation of this link either, see Arai-Takahashi, supra n.1, p. 90 and 94.

${ }^{79}$ Carozza, supra n. 61, p. 61-63.

${ }^{80}$ Letsas, supra n. 1, p. 722, referring to chronological, procedural and normative priority alike as part of the rationale for the structural margin of appreciation.
} 
logically relevant to each of the two elements. Conclusions on deference to others under the systemic margin would focus on the characteristics and capacities of the other decision-making body, or the quality of its decision-making process, while own assessments under the normative margin would draw on the relevant substantive characteristics of the issue under consideration, such as the type of right at stake or the type of interests protected by it. ${ }^{81}$

These different types of reasoning correspond more or less to Raz's account of constitutional interpretation as legitimately consisting of two types of reasons. The first category is 'merits reasons', which relate to the normative substance or merit of constitutional provisions, but the latter consists of 'non-merit reasons' which relate to other (e.g. political or systemic) concerns that may also have a role to play. ${ }^{82}$ While he argues that merits reasons are the most important ones in constitutional interpretation, he also submits that non-merits reasons may have a legitimating role and be relevant depending on context. ${ }^{83}$ The more important merits reasons are first order reasons, but on Raz's account they nevertheless do not always defeat the less important secondary non-merits reasons. For example, the constitutional text might be interpreted differently from what would otherwise be required on the balance of merits reasons 'to placate a hostile legislature or executive, which may otherwise take action to limit the power of the courts or to compromise their independence'. ${ }^{84}$ This depiction of the constitutional interpretative process, of course, presupposes normative engagement by an interpreter. According to Raz, however, non-merits reasons can also function as 'exclusionary'. Instead of influencing a decision on interpretation, such non-merits reasons may 'imply that one ought not to act on the balance of reasons' at all. ${ }^{85}$ Raz's example of Ann, who decided not to decide on an investment option due to her tiredness, exhibits how this works. Here, Ann's tiredness was an exclusionary reason that simply cancelled any engagement with the merits of the investment. ${ }^{86}$ Similarly, in the context of interpretation, if a non-merits reason is exclusionary, this means that instead of engaging with the balancing of all the (merits and nonmerits) reasons relevant to the interpretation or application of a right, the interpreter simply does not engage normatively.

\footnotetext{
${ }^{81}$ See generally H. Richards, 'Deference', 74 Ethics (1964) p. 135 at p. 139.

${ }^{82}$ Raz, supra n. 69, p. 172 and 187.

${ }^{83}$ Raz, supra n. 69, p. 187. See also A. Kavanagh, 'Deference of Defiance?: The Limits of the Judicial Role in Constitutional Adjudication' in G. Huscroft (ed.), Expounding the Constitution Essays in Constitutional Theory (Cambridge University Press 2008) p. 184 at p. 190.

${ }^{84} \mathrm{Raz}$, supra n. 69, p. 187.

${ }^{85}$ Raz, supra n. 13, p. 41.

${ }^{86}$ Raz, supra n. 13, p. 37. See also E.A. Christodoulidis, Law and Reflexive Politics (Kluwer 1998) p. 227.
} 
As already mentioned, Legg conceptualises the margin of appreciation as exclusively related to his three types of 'external' non-merits reasons (democracy, European consensus, expertise) that influence the Court's assessment of the first order merits reasons. ${ }^{87}$ From the internal hermeneutic perspective, however, this conceptualisation of the margin and the structure of the Court's reasoning is quite problematic. ${ }^{88}$ As the Court indeed not only locates the margin of appreciation on such non-merits reasons, but also on the consideration of various merits-based reasons, it simply does not reflect the case law accurately enough. ${ }^{89}$ Since both types of reasons are part of the Court's practice, the distinction between the systemic and normative elements of the margin of appreciation as elaborated above can provide the clarity missing from previous theoretical accounts of the margin of appreciation doctrine.

Exhibiting this distinction in practice the Court, for example, in Dogru emphasised that 'the role of the national decision-making body must be given special importance', and that the national authorities were 'best placed' to assess the situation (non-merits reasons under the systemic margin), ${ }^{90}$ while also relying on the substantive rationale that the wearing of religious symbols on school premises could be a 'source of pressure and exclusion' and on the nature of the 'delicate relations between the Churches and the State' (merits reasons under the normative margin). ${ }^{91}$ Similarly in Folgerø and Others, it reasoned systematically that decisions on school curriculum involved 'questions of expediency on which it is not for the Court to rule' and which fell 'in principle within the competence of the Contracting States', while also reasoning normatively that no indoctrination can be involved. ${ }^{92}$ As exhibited by these judgments, the 'better placed' argument

${ }^{87}$ Legg, supra n. 1, p. 8-9 and 196.

${ }^{88}$ On the hermeneutic perspective see N. MacCormick, H.L.A. Hart (Stanford University Press 1981) p. 38; J. Bell, 'Legal Research and the Distinctiveness of Comparative Law' in M. Van Hoecke (ed.), Methodologies of Legal Research Which Kind of Method for What Kind of Discipline? (Hart 2013) p. 155 at p. 159 .

${ }^{89}$ Consider, for example, the following examples: Evans v United Kingdom, supra n. 45, para. 77 ('where a particularly important facet of an individual's existence or identity is at stake, the margin allowed to the State will be restricted'); ECtHR 4 December 2007, Case No. 44362/04, Dickson v United Kingdom, para. 77 ('The breadth of this margin varies and depends on a number of factors, including the nature of the activities restricted and the aims pursued by the restrictions'); ECtHR 4 December 2008, Case Nos. 30562/04 and 30566/04, S and Marper v United Kingdom, para. 102 ('The margin will tend to be narrower where the right at stake is crucial to the individual's effective enjoyment of intimate or key rights').

${ }_{90}$ Dogru v France, supra n. 45, paras. 63 and 75 respectively.

${ }^{91}$ Dogru v France, supra n. 45, paras. 71 and 72 respectively.

${ }^{92}$ Folgerø v Norway, supra n. 46, para. 84. Although the Court identified other problems with the contested obligatory religious education course, it concluded that emphasis on Christianity per se, pursued in the context of no indoctrination, would fall within the State's margin of appreciation in planning and setting the curriculum, see para. 89. See also Lautsi and Others v Italy, supra n. 45, para. 62. 
or similar non-merits reasons are most often part and parcel of judgments where the Court engages on the merits. ${ }^{93}$ The different rationales related to the systemic and normative margins of appreciation, therefore, often interact. Such partial reliance on the national authorities' judgment should therefore be taken as only a factor influencing the Court's own interpretation and review, but not as substitute for it. In exceptional instances, however, systemic non-merits reasons can be relied upon as exclusionary reasons that result in the fact that the Court does not engage normatively on certain elements of the case before it. ${ }^{94}$ This has most notably occurred in cases under the 'fourth instance doctrine' where the Court is asked to reassess the national courts' fact finding or interpretation of domestic law; ${ }^{95}$ in the Von Hannover (No. 2) type of situation when it is asked to reconsider the proportionality assessments of diligent national courts when balancing interests under two equally protected Convention rights; ${ }^{96}$ and in the Bosphorus Airways type of situation when it is asked to assess the proportionality of 'directly applicable' measures of EU law that leave States no discretion in implementation. ${ }^{97}$ We will now turn to examining cases involving exclusionary non-merits reasons in more detail.

\section{Complete and partial deference}

Seeking a deeper understanding of the two different elements of the margin of appreciation, it is helpful to note that in moral reasoning, there is a difference between assuming the authority or competence to make a moral assessment and actually making one. ${ }^{98}$ Deference, on one reading, is shown when the person or body in question does not assume the role of assessing a situation, and leaves it instead to some other person or body. ${ }^{99}$ This does not necessarily have to mean

\footnotetext{
${ }^{93}$ For an additional example see Beganović v Croatia, supra n. 25, para. 80, where the Court reasoned that 'provided that criminal law mechanisms are available to the victim' (merits reasons), 'the choice of the means to secure compliance with Article 3 in the sphere of the relations of individuals between themselves is in principle a matter that falls within the domestic authorities' margin of appreciation' (non-merits reasons).

${ }^{94}$ The Court may, however, engage normatively on other elements of the same case, see, for example, ECtHR 3 July 2012, Case No. 34806/04, Xv Finland, paras. 216-222, where the Court categorically and completely deferred with respect to the interpretation and application of national law, but proceeded to the classic normative assessment under Art. 8(2) of the quality of the law authorising interference (quality, accessibility and foreseeability).

${ }^{95}$ For example Koval v Ukraine, supra n. 24, para. 115; and ECtHR 1 June 2006, Case No. 25921/02, Fedorenko v Ukraine, para. 27.

${ }^{96}$ ECtHR 7 February 2012, Case Nos. 40660/08 and 60641/08, Von Hannover v Germany (No. 2).

${ }^{97}$ ECtHR 30 June 2005, Case No. 45036/98, Bosphorus Hava Yollar Turizm ve Ticaret Anonim Sirketi v Ireland.

${ }^{98}$ Richards, supra n. 81, p. 135.

${ }^{99}$ Richards, supra n. 81, p. 138.
} 
that the person or body does not have the authority to assess the situation; it can also simply mean that they have chosen not to engage a vested authority. ${ }^{100}$

More precisely, situations where a person or body does not assume the role of assessment at all can be referred to as instances of complete deference, or as indicating deference in the narrow sense. Under the Convention, this would mean that the Court simply proceeds on the basis of the assessment of the body deferred to. The term deference, to be sure, can also be taken to encompass partial deference where the opinions of others are taken into account as factors that influence own assessments of a situation. ${ }^{101}$ In this latter instance, the assessment of others, as relevant under the systemic element, is a factor of variable strength in an overall assessment that also engages the normative element of the margin of appreciation. In the Convention context, the concept of deference is often used in this wider sense. ${ }^{102}$ The common unqualified use of the term, however, is unhelpful for making sense of the margin of appreciation because it masks an important difference between the two elements of the margin of appreciation: the fact that non-merits reasons under the systemic element can theoretically be exclusionary and have the function that the Court does not assume competence vis-à-vis another decisionmaking body to make a moral/judicial assessment at all (complete deference), while the normative element always implies substantive engagement by the Court.

Deference and own judgment, however, often intersect when making moral/ legal assessments. Consider the example of a person saying 'I think Judy is right - in the long run it would not be good for any of us. ${ }^{103}$ It is readily apparent that this person combines deference to Judy's assessment and her own judgment of the underlying moral question to come to a conclusion. So too for the European Court

\footnotetext{
${ }^{100}$ See Spielmann's reference to parts of the doctrine as a tool by which the Court may 'waive' its power of review in D. Spielmann, 'Allowing the Right Margin: The European Court of Human Rights and the National Margin of Appreciation Doctrine: Waiver or Subsidiarity of European Review', 14 Cambridge Yearbook of European Legal Studies (2011-2012) p. 381 at p. 384.

${ }^{101}$ Kavanagh, supra n. 83, p. 186, explains how 'deference is a matter of degree depending on how much weight A assigns to B's judgment', which can range from situations of 'partial deference' to 'absolute or complete deference' (emphasis on original). This was described as the difference between 'deference as respect' and 'deference as submission' by D. Dyzenhaus, 'The Politics of Deference: Judicial Review and Democracy' in M. Taggart (ed.), The Province of Administrative Law (Hart 1997) p. 279 at p. 303. P. Soper, The Ethics of Deference: Learning from Law's Morals (Cambridge University Press 2001) p. 20, uses the analogy of requests and orders to describe the same difference. Similarly, see Raz, supra n. 13, p. 101. For the development of three categories of deference along the axis of 'submission' to own assessments in the context domestic law, see A. L. Young, 'In Defence of Due Deference', 72 MLR (2009) p. 554 at p. 560-563.

${ }^{102}$ Legg, supra n. 1, p. 17 and 21 uses the concept of deference in this unqualified manner, and understands deference as always partial. See also, for example, Kratochvíl, supra n. 2, p. 327 and Yourow, supra n. 52, p. 13.

${ }^{103}$ Example taken from Richards, supra n. 81, p. 139.
} 
of Human Rights, when it for example partly relies on the quality of the local decision-making process behind a particular national policy or action, and partly on its own normative proportionality assessment, to reach a conclusion on whether it is in violation of Convention standards. ${ }^{104}$ The Court may also emphasise that for reasons of 'direct democratic legitimation' and 'contact with the vital forces of their countries', the national authorities are 'better placed' than the Court to make the initial assessments in the case, while reasoning nevertheless that the relevant final evaluation of the Convention compatibility of the contested measure is the Court's. ${ }^{105}$ Here again, the Court takes the assessments of the national authorities into consideration under the systemic margin, while also engaging itself under the normative margin. This kind of partial deference is, for example, exhibited in the Dogru and Folgero and Others judgments discussed supra. In such cases, the fact that the Court itself does engage normatively with the relevant substantive issue indicates that it nevertheless in the final analysis exercises its authority under Article 32 ECHR to have the last say on the interpretation and application of Convention standards. Thus, while engaging the systemic and normative elements of the margin of appreciation alike and indicating partial deference in the wider sense, they do not indicate complete deference in the narrower sense. The rationales for deference (non-merits reasons) and own assessments (merits reasons), therefore, intersect in cases of this kind. ${ }^{106}$ At the same time, the partial deference implied may have a legitimising effect in relation to the final outcome.

While being the most common situation, such partial deference engaging the systemic and normative elements alike is by no means the only possible result of applying the margin of appreciation doctrine. The Court may also in some instances defer completely to other decision makers as judgments under the 'fourth instance doctrine' exhibit (see supra). More recently, the Court has also devised a new use for the margin of appreciation doctrine in cases where two protected private interests collide and have to be balanced against each other under competing Convention rights. ${ }^{107}$ When elaborating the margin of appreciation

\footnotetext{
${ }^{104}$ See, for example, Hatton and Others v United Kingdom, supra n. 65. Compare paras. 122-127 (own proportionality assessment) and para. 128 (national decision-making process).

${ }^{105}$ E.g. ECtHR 3 April 2012, Case No. 42857/05, Van der Heijden v Netherlands, paras. 56-57.

${ }^{106}$ Kavanagh, supra n. 83 , p. 190 , referring to this intersection of rationales to support the conclusion that both are part of the interpretative process in national constitutional law.

${ }^{107}$ This group of cases is referred to by Spielmann, supra n. 54, p. 63 as exhibiting the 'systemic' objective of the doctrine. Commentators are only beginning to make sense of it, see Arai-Takahashi, supra n. 1, p. 92, who briefly notes its existence in a footnote; and B. Çali, 'Towards a Responsible Domestic Courts Doctrine? The European Court of Human Rights and the Variable Standard of Judicial Review of Domestic Court Judgments' in O. M. Arnardóttir and A. Buyse (eds.), Shifting Centres of Gravity of Human Rights Protection Rethinking Relations between the ECHR, EU and National Legal Orders (forthcoming, Routledge 2016), on file with author.
} 
relevant to such assessments, and instead of relying on the classic approach of asserting its role to assess the reasons put forward by States in support of their action and performing its own proportionality review, ${ }^{108}$ the Court stated that ' $[\mathrm{w}]$ here the balancing exercise has been undertaken by the national authorities in conformity with the criteria laid down in the Court's case law, the Court would require strong reasons to substitute its view for that of the domestic courts'. ${ }^{109}$ The Court has, therefore, created what can best be described as a presumption of complete deference to the national courts in situations of this kind. This presumption, however, is rebuttable. It 'presupposes that an effective legal system was in place and operating for the protection of the [relevant] rights', ${ }^{110}$ and it is also conditioned upon the national Courts having exercised due diligence in applying Convention principles, as developed by the Court, to the facts of the case. If they have, the Strasbourg Court will defer to their proportionality assessment, but if not the Court will step in and perform its own. This new approach was introduced and confirmed in four key judgments, which all concerned the balancing of Article 10 against Article 8. In MGN, Von Hannover (No. 2) and $A k s u$, after reviewing the quality of the national court's reasoning, the presumption of complete deference held. ${ }^{11}$ Exhibiting the strength of the presumption, the Court in one of these judgments actually through its own assessment identified a problematic issue, but decided nevertheless that 'this element alone is insufficient for the Court to substitute its own view for that of the domestic courts'. ${ }^{12}$ The Axel Springer judgment, however, lies at the other end of the spectrum. Here, the presumption of deference was referred to, but did not

\footnotetext{
${ }^{108}$ For the classic approach, see, for example, ECtHR 22 October 2007, Case Nos. 21279/02 and 36448/02, Lindon, Otchakovsky-Laurens and July v France, para. 45.

${ }^{109}$ ECtHR 7 February 2012, Case No. 39954/08, Axel Springer AG v Germany, para. 88; Von Hannover v Germany (No. 2), supra n. 96, para. 107. This new approach was originally developed in slightly different language in ECtHR 12 June 2012, Case No. 39401/04, MGNv United Kingdom, para. 150 and Palomo Sánchez and Others, supra n. 47, para. 57.

${ }^{110}$ ECtHR 15 March 2012, Case Nos. 4149/04 and 41029/04, Aksu v Turkey.

${ }^{111} M G N$ v United Kingdom, supra n. 109, paras. 145-156, where the Court did 'not find any reason, let alone a strong reason, to substitute its view for that of the final decision of the House of Lords' (para. 155). The second case is Von Hannover v Germany (No. 2), supra n. 96, paras. 114-126, where the Court concluded on how 'national courts carefully balanced' the competing rights (para. 124), and how they 'explicitly took account of the Court's relevant case-law' (para. 125). Only in para. 120 did the Court add a minor own comment to the effect of confirming the assessment of the domestic court. The third case is Aksu v Turkey, supra n. 110. As regards the facts of Case No. 4149/04, see paras. 69-77, where the Court was 'satisfied that [...] the Turkish courts made an assessment based on the principles resulting from the Court's well-established case-law'. Only in para. 70 did it add some limited own remarks when confirming the assessment of the domestic court.

${ }^{112}$ Aksu v Turkey, supra n. 110, para. 86, see also paras. 84-85.
} 
hold at all, and the Court performed the classic full de novo proportionality assessment under the Convention. ${ }^{113}$

The above position of principle on competing rights in fact resembles the 'presumption of Convention compliance' established for EU law in the Bosphorus Airways judgment. Here, and against the background of the Contracting State's obligations when EU law leaves it no discretion in implementation, the Court had to assess whether the impounding of an aircraft according to EC Council Regulation No. 993/93 was in violation of Article 1 Protocol 1. As usual, the Court began its assessment by restating in general terms the key elements of the relevant Convention principles and the (wide) margin of appreciation applicable in similar situations. ${ }^{114}$ But, interestingly, instead of proceeding on the classic approach and applying these principles in concreto to the facts of the case, the Court changed its analytical model. It stated that in situations where the respondent state is simply acting in 'compliance with obligations flowing from its membership of an international organisation to which it has transferred part of its sovereignty', ${ }^{115}$ its actions are 'justified as long as the relevant organisation is considered to protect fundamental rights, as regards both the substantive guarantees offered and the mechanisms controlling their observance, in a manner which can be considered at least equivalent to that for which the Convention provides'. ${ }^{116}$ Therefore, the Court held that when it comes to the conclusion - as it did for the EU - that such equivalent protection is provided, 'the presumption will be that a State has not departed from the requirements of the Convention when it does no more than implement legal obligations flowing from its membership of the organisation'. ${ }^{117}$ It added that this presumption could be

${ }^{113}$ Axel Springer A G v Germany, supra n. 109, paras. 96-110. The Dissenting Opinion of Judge López Guerra, Joined by Judges Jungwiert, Jaeger, Villiger and Palelungi, however, held that since the domestic courts had duly performed the required balancing exercise, 'none of the grounds which would justify a review by this Court of the judgments of the domestic courts are present'. In subsequent judgments the presumption of complete deference has been rebutted in situations where 'the national courts did not carefully balance the journalist's right to freedom of expression against the applicant's right to respect for his private life', see ECtHR 28 October 2014, Case No. 20531/06, Ion Cârstea v Romania, para. 38. Somewhat problematically, the Court may also sometimes refer to the presumption of Convention compliance, but apply the classic approach of its own proportionality review in part or in full, rendering the case-law on competing private interests somewhat confusing, see, for example, ECtHR 4 December 2012, Case No. 59631/09, Verlagsgruppe News GmbH and Bobi v Austria; and ECtHR, 24 October 2012, Case No. 40721/08, Fáber v Hungary. For a fuller analysis of the relevant case-law, see O. M. Arnardóttir, 'Organised Retreat? The Move from 'Substantive' to 'Procedural' Review in the ECtHR's Case Law on the Margin of Appreciation', 5(4) ESIL Conference Paper Series (2015), <papers.ssrn.com/sol3/papers.cfm?abstract_id=2709669>, visited 24 February 2016.

${ }^{114}$ Bosphorus Airways, supra n. 97, paras. 149-151.

${ }^{115} I d$., para. 154.

${ }^{116} I d$., para. 155.

${ }^{117}$ Id., para. 156. 
rebutted only if, "in the circumstances of a particular case, it is considered that the protection of Convention rights was manifestly deficient'. ${ }^{118}$

In sum, all the examples discussed here ('fourth instance', competing rights under Articles 8 and 10, EU law) exhibit such a decisive reliance on systemic non-merits rationales that the result, under certain conditions, can be complete deference. ${ }^{119}$ The distinction between such complete deference and own assessments is no stranger to legal thinking and has been identified as an important element of understanding doctrines of deference in the context of national law. ${ }^{120}$ The EU preliminary rulings procedure is also an interesting example of how this distinction can work in practice, as the relevant legal rules clearly define the international court's role as limited to the provision of interpretative guidance (own normative engagement only on interpretation), while leaving the task of application of norms so interpreted to the national courts (complete deference on application in concreto). ${ }^{121}$ It is somewhat surprising, therefore, that the literature on the margin of appreciation under the Convention has not paid much attention to it. ${ }^{122}$ The difference between deference to others and own assessments is also important for the reason that resolving who has competence to decide logically precedes deciding the question of substance. ${ }^{123}$ If the person or body contemplating whether to make a

${ }^{118} I d$.

${ }^{119}$ When originally introduced, concurring and dissenting judges expressed great unease over the move vis-à-vis EU law and competing rights, see id., Joint Concurring opinion of Judges Rozakis, Tulkens, Traja, Botoucharova, Zagrebelsky and Garlicki, paras. 3 and 4; Palomo Sánchez and Others v Spain, supra n. 47, Joint Dissenting Opinion of Judges Tulkens, Davíd Thór Björgvinsson, Jočiené, Popović and Vučinić, para. 10; and MGN v United Kingdom, supra n. 109, Dissenting Opinion of Judge Davíd Thór Björgvinsson, para. 5.

${ }^{120}$ Dyzenhaus, supra n. 101; Kavanagh, supra n. 83; Young, supra n. 101.

${ }^{121}$ Article 267 TFEU. The use of the margin of appreciation in recent cases concerning the balancing of competing Convention rights has been described as resembling this structure of judicial decision-making, see O. M. Arnardóttir and D. Guðmundsdóttir, 'Speaking the Same Language? Comparing Judicial Restraint at the ECtHR and the ECJ ' in O. M. Arnardóttir and A. Buyse (eds.), Shifting Centres of Gravity of Human Rights Protection Rethinking Relations between the ECHR, EU and National Legal Orders (forthcoming, Routledge 2016), on file with author. It should be noted, however, that the structure provided for in Article 267 TFEU has not always prevented the ECJ from giving guidance so specific that it can be equated with full review, see $\mathrm{T}$. Tridimas, 'Constitutional review of member state action: The virtues and vices of an incomplete jurisdiction', $9 \operatorname{ICON}(2011)$ p. 737 at p. 739.

${ }^{122}$ This distinction was, however, mentioned by Spano, supra n. 55, at p. 494, who argued that the Court's role lies on a spectrum ranging from full de novo review of domestic decisions (as under Arts. 2 and 3) to 'full and unlimited deference' (which he argues is uncommon, but may be at issue in difficult cases under Arts. 6, 8-11, and Art. 1of Protocol 1).

${ }^{123}$ Richards, supra n. 81, p. 136; Horsley, supra n. 61, p. 281. See also J. Gerards, 'Procedural review by the ECtHR - a typology', (forthcoming book chapter) on file with author, who argues that 
moral/judicial assessment decides it does not have or does not engage a vested authority at all, the matter ends there and no substantive assessment is made.

In conclusion it is submitted that the difference between full and partial deference, and the logical consequences thereof, can be better reflected under the margin of appreciation doctrine if it is more clearly conceptualised as entailing the systemic and normative elements as elaborated in this article. The rethought conceptualisation thus highlights how an increased focus on the systemic element of subsidiarity and margin of appreciation can have the practical result that the Court pronounces on the merits of fewer cases in concreto. ${ }^{124}$ This has obvious consequences for the Court's workload, but also for any normative assessment of how the Court wields its authority under Article $32 \mathrm{ECHR}$, which charges it with the judicial responsibility of deciding all matters concerning the interpretation and application of the Convention and its Protocols.

\section{Conclusions: Calling a SPADE A SPADE}

\section{The cause for a rethink}

The literature on the margin of appreciation has hitherto not made a distinction between the systemic and the normative elements of the margin of appreciation doctrine as elaborated in this article. It has, in other words, generally not differentiated between deference to others for non-merits reasons and variable standards of review in the Court's own assessment of merits reasons. While a distinction of this kind was helpfully suggested by Legg, it was at the same time taken to the questionable conclusion that the margin of appreciation has no proper function in relation to merits reasons and inherently only relates to non-merits reasons, which also can never be 'exclusionary' in the form or preventing normative engagement by the Court. The literature is, further, generally focused on situations of partial deference where the systemic and normative rationales behind the margin of appreciation intersect, and the Court's normative role is engaged in concreto. This also applies to Letsas' well-known dual conceptualisation of the margin of appreciation. Even in the 'structural' conception, Letsas' approach is that the doctrine's function of limiting the powers of the Court

the omission of any substantive review is the 'full logical consequence' of increased attention to the quality of domestic decision-making processes in the Court's review model.

${ }^{124}$ This is one of the obvious consequences of applying Janneke Gerards' idea that 'procedural review' should always precede 'substantive review', making the latter redundant in some types of cases, see Gerards, supra n. 8. While she argues that such an approach 'would reduce the need to apply the margin of appreciation doctrine' (p. 200), the Court itself seems to be embracing the doctrine as the mechanism through which to introduce it, see, for example, Von Hannover v Germany (No. 2), supra n. 96. 
only leads to the making of a qualified substantive judgment, ${ }^{125}$ where it relies 'heavily, but not exclusively' on the national authorities' judgment, and the margin of appreciation functions to 'express the degree to which' this takes place. ${ }^{126}$ On Letsas' construction, then, the two margins of appreciation both rely on merits and non-merits reasons alike, and perform very similar functions. Although they can be taken to express differences in degree with respect to the width of the margin of appreciation in situations of partial deference, it is hard to see the clear difference in kind.

If a theory of the margin of appreciation is to perform the heuristic function legitimately expected of legal theories, it must reflect the Court's case law as much as possible, and be able to tell us more about the different functions it performs and the different rationales that support them. With all due respect to the important contributions of Letsas, Legg and other commentators, it was therefore concluded that the time has come to rethink how the margin of appreciation doctrine has been conceptualised in the literature.

\section{The rethought two elements of the margins of appreciation}

Upon rethinking, it was concluded that the literature on the margin of appreciation doctrine has correctly identified two different functions for the doctrine, but that the lack of clarity and consensus on the dividing line between them, and on the consequences of the distinction, has hampered the development of a clear theoretical vision for the doctrine. Seeking to elaborate a theory focused on these two different functions, it was suggested that the two elements of the principle of subsidiarity, as elaborated in the literature, should be brought to bear on the doctrine. Accordingly, the margin of appreciation should be conceptualised as consisting of two elements. First is the systemic element, which like the systemic element of the principle of subsidiarity relies on a functional or pragmatic rationale related to the different competences of different actors in the European system for the protection of human rights, and has the function of influencing distribution of tasks between them. The second element is the normative one, which has a normative justification related to pluralism and flexibility and has the function of influencing how rights are interpreted and applied. Drawing on insights from moral reasoning, it was also established how different types of reasoning are relevant to each element as the systemic element draws on non-merits reasons, while the normative element relies on merits reasons. It was also exhibited how this is, indeed, reflected in the case law of the Court. Finally, and drawing on the

\footnotetext{
${ }^{125}$ Letsas, supra n. 1, p. 721 (on structural margin): 'I here refer to the tests employed to show whether interference with an individual right amounts to a violation under the various moral theories of human rights'.

${ }^{126} I d$., p. 721 and 722 respectively (emphasis added).
} 
literature on constitutional interpretation, it was argued that the distinction between complete and partial deference is important and should be brought to bear when theorising the doctrine. It was explained how the rethought two margins of appreciation are indeed capable of reflecting this difference, as complete deference can only occur under the systemic element of the doctrine, which also logically precedes the Court's own normative assessment of a case. The rethought version of the two margins of appreciation presented herein, therefore, provides a grasp on the case law where the systemic margin of appreciation is decisively relied upon; a grasp that theoretical accounts of the margin of appreciation have hitherto not been able to provide.

Defining the two elements of the margin of appreciation, it can be stated that the systemic one is related to deference to other decision-making bodies for non-merits reasons, and that the normative element is related to the Court's own assessment of merits reasons. In the former conception the margin of appreciation has a distinct systemic ('structural' or 'procedural') function related to the division of tasks within the European system for the protection of human rights, whereas the latter conception has a normative ('substantive') function and reflects pluralism and normative flexibility in the interpretation and application of Convention rights. The systemic and the normative elements of the margin of appreciation can intersect in various ways within the same case. In its purest or most extreme form, the systemic element of the margin of appreciation can exert such a strong influence on the Court's reasoning that the end result may best be described as complete deference to other actors in the European system for the protection of human rights on certain elements of a case. More often, however, it interacts with normative merits reasons, resulting in partial deference. In such cases, a decisive reliance on the systemic rationale generally functions as an indicator for more lenient review.

The rethought version of the two margins of appreciation presented herein enables the clearer understanding of the doctrine so often called for in the literature. It is submitted, therefore, that it greatly enhances our chances of making sense of the Court's case law, and the capacity for normative assessment of how the Court uses the powers vested in it. In the final analysis, it enables us to call a spade a spade instead of continuing to dabble in muddy waters. 